THURSDAY, DECEMBER 4, 1873

\section{DR. MEYER'S EXPEDITION TO NEW GUINEA}

REFORE giving to the readers of NATURE a brief account of my own voyage to New Guinea, from which island I have just returned, I shall say a few worls about some other expeditions to this "far-east" and interesting island, undertaken within the last two years by various governments and private individuals.

In $187 \mathrm{I}$ the Dutch Government sent out a steamer and specially appointed officials, to circumnavigate the entire island of New Guinea, land from time to time, and take formal possession of those parts of the country which did not yet belong to the Dutch. It is known that this nation has hitherto had only a certain rightover the western part of New Guinea as far as $14 \mathrm{I}^{\circ} \mathrm{E}$. ; and before going farther the expedition had to erect sign-posts in the name of the Dutch Government at different parts of western New Guinea. But this first expedition did not attain its end; a few posts were set on the north coast, the farthest east being on Humboldt Bay, on the frontier of the Dutch territory; the expedition tried to go still farther east, but was obliged to return in a very bad condition, without having fulfilled its task.

In 1872 the Dutch sent out a second expedition in a small steamer for the same purpose; but this one did not succeed in going even so far east as the first, and was likewise obliged to return, after a very short time, without any result.

It is now proposed to try another expedition on a larger scale in 1874 , which will go first through Torres Strait to the east, and afterwards, along the north coast, to the west ; but I am not sure that this plan will be carried out.

In 1870 some Italians, under the guidance of M. Cerruti, who had been several times in New Guinea before (1861, 1865, and 1866), visited in a little schooner a part of the south-west coast, for the purpose of looking out for a convict settlement for their Government, and explored chiefly the straits between the island of Salwatty and the mainland. They were attacked in MacCluer Gulf, and the combat that took place was much spoken of in Dutch India during my sojourn there.

In 1872 two Italian naturalists, M. Beccari and M. d'Albertis, endeavoured to visit the mainland of New Guinea at a place on the south-west coast, called Utanate, which had been previously visited by the Dutch; but they could not reach it, on account of currents and winds. They remained for some time longer to the westward of the south-west coast and at Sorong, between the island of Salwatty and the mainland (where in the beginning of 1873 eighteen Europeans from an Australian pearlfisher were murdered by the Papooas*), then proceeded to Dorey, in the north, and made a station on the Arfak Mountains. They returned in November 1872, an Italian man-of-war being sent by their Government to look after them.

During the same time a Russian traveller, Mr. Maclay, had been on the north-west coast of New Guinea, in Astrolabe Bay. He was brought thither, and fetched away after more than a year's stay, by a Russian man-

* I write Papooas, and not Papuas, because the Malays pronounce the word "Papooa," and not "Papua."

VOL, IX. - No. 2I4 of-war; his plan to cross the mainland of New Guinea in any direction could not be effected, as was to be foreseen by those who know something about the special difficulties of travelling in New Guinea. He only moved about the district extending some miles round his station. Before I started on my expedition I met, in the beginning of this year, in Ternate (Molukkas Islands), the Russian man-ofwar, coming back from New Guinea. Although she had only stayed in Astrolabe Bay for five days to take in water and wood, still, two months later, more than eighty of the ship's officers and crew were attacked by fever.

Finally, the news which reached Europe from Australia in respect to New Guinea, and which had already in $187 \mathrm{I}$ made the Dutch send a man-of-war round that continent, to inspect how far the plans of the "New Guinea Prospecting Association" were ripening, this news, as well as the end of the expedition of this Association in 1872 , are better known in England than the other undertakings which I have roughly sketched above.

The proposed and partly effected settlement of missionaries of the London Missionary Society on the islands of Torres Strait, and that proposed to be made on the south coast of New Guinea itself, are likewise known.

Whether the news, published in an Australian paper, that the English had taken possession of the extreme south-east shore of New Guinea, be true or not, I am not able to say. But from what has been said it may be concluded that the eyes of civilised nations are now fixed more on New Guinea than ever, and that results will be sure to follow. What these results may be, and what prospects all these exertions may present in respect to the character of the country and its inhabitants, I will not take into consideration now, but proceed to a sketch of my own voyage.

On my previous travels, which went as far as the Island of Celebes and the Philippine Islands, I had gathered sufficient information to know which would be the easiest way to reach New Guinea, and how to find the best place for a station. I was aware of the impossibility of penetrating into the interior of the larger part of this large continent, if my expedition were not of much larger dimensions, and if it could not command much ampler means than are available to a private person like myself, and chiefly if it would not lose its character of a natural history expedition, and become solely a geographical exploration. On another occasion I shall show how such a geographical expedition through New Guinea could be started by one individual or by a company of travellers, and to what parts it would be most advantageous to proceed at first. The peculiarities of the country and the natives are such, that there are even more difficulties for travellers here than there are in Australia, where the best-fitted-out expeditions and the most able and courageous men have failed. In New Guinea it is even a question, whether the scientific or practical results are likely to be at all equal to the expenditure and the great danger connected with such an undertaking.

Being obliged, therefore, to resign the eastern and larger half of the island, I had to choose for a starting-point only between the south-west coast, from opposite the Aru Islands to Salwatty, and the coast:s of Geelvinks Bay. I preferred the latter, for several strong reasons which weighed against the south-west coast, and 
in favour of Ge elvinks Bay; among others were the unhealthiness of the swampy shores of the south-west coast, the fact that the natives of these parts have been more influenced by Malay traders for centuries than those of the northern regions, and therefore are less original, and that the south-west coast has been visited oftener by Europeans.

In consequence of the time consumed in making all necessary preparations, I only reached New Guinea in the beginning of March of this year, and anchored the little schooner, which I had hired in Ternate(I preferred this place as a starting-point to Amboina) -in the harbour of Dorey, in the north-west corner of Geelvinks Bay, the only part of all New Guinea where any Europeans, German and Dutch missionaries, are settled. With me, and in my service on board the ship, over which I had full disposal, were, besides about fifteen Malay sailors and a Malay captain, twenty natives from different parts of the Malay Archipelago.

Dorey has been described, among others, by $\mathrm{Mr}$. Wallace, but he has, in my opinion, not given a correct impression of the natives of the surrounding hills and mountains, separating them in some way from the inhabitants of the coast, as smaller, uglier, not mopheaded, \&c. As I afterwards spent a long time among the natives of the Arfak Mountains, near Dorey, and the inhabitants of the different parts of the coast of Geelvinks Bay, the islands in the north of it, and the interior of this whole north-west part of New Guinea, I may state, that there is no generic difference at all between the Papooas of the mountains and the Papooas of the coast--except such differences as we find everywhere between the highlanders and coast inhabitants of the same race.

The changing of the West into the East Monsoon, to be expected in April, obliged me to visit first the islands in the north of Geelvinks Bay, if I wished to visit them at all; and therefore, after a three days' stay at Dorey and neighbourhood, I immediately started for Mafoor, a smaller island, only about sixty miles from Dorey. It took me more than forty-eight hours to reach it. Mafoor offered me nothing particular, besides its zoological productions; it is only interesting, for having been at an earlier period the chief seat of the Mafoor tribe, which now inhabits all the coasts of the western part of Geelvinks Bay.

The island of Mysore (Willem Schouten's island), the furthest north and a larger one, was far more important for my purposes. The natives were at first of a hostile disposition, but we soon became friends, and I spent here a most interesting time, in consequence of the results of my collections and what I saw of the Papooas, wild and nearly unmodified tribes, with all the virtues and vices of such. I commenced to make a collection of Papooan skulls here, in which at last I was so successful, that I hope to be able now, by means of my large materials, to trace at least the limits of the variation which the skull of this race undergoes, and finally to fix the type of the Papooan skull,-important questions, which craniology can solve.

On Mysore, Birds of Paradise, as well as the Kasuary, are unknown; but it as well as the large island of Jobie, which I now visited, is the home of the fine Crown pigeon (Goura victoria). This beautiful bird occurs in such quantities, that it furnished us with our daily meals during nearly the whole of our stay on Mysore and Jobie. The flesh is most tender and delicate, preferable to any fowl I know of.

Jobie has for long had the reputation of being the home of many species of rare birds of Paradise; I am sorry to be obliged to rob it of this glory. I only got Paradisea papuana (but with more splendid, deeper orange and longer side feathers than from the mainland of New Guinea), P. regia and Diphyllodes speciosa. $P . p a-$ puana is not rare, but very local, so that one may hunt for weeks in the mountains, without finding a single specimen (females and young males are seen and heard much oftener than males in their plumage) ; but if once a tree is found where they feed and "dance," a lot of them can be got together. P. regia is rare, and $D$. speciosa very difficult to get here.

I am sure that no other species of Birds of Paradise come from Jobie, as no other species are in the hands of the Papooan traders. I am convinced of this, because I stayed a long time at the chief place of the island, Ansus, a very populous settlement, where I saw and heard everything; more than two thousand Papooas are living here together, all in those large, curious houses, standing entirely on the water. But other species of Birds of Paradise which I showed (I had obtained some in Ternate and Dorey on my way), were unknown even to the inhabitants here, except to those who had been on the mainland. I mention this fact, notwithstanding that $I$ had not the intention of giving any zoological details in this account, because it may be seen, how erroneous it was to give credit to the natives of New Guinea, who pretended that some rare birds of Paradise came from Jobie, certainly with the purpose of withdrawing attention from their own country, where these birds are to be found.

In general the fauna of Jobie is very poor, as well in respect to different species as to the mass of individuals of one species.

The inhabitants of the mountainous parts of Jobie are known to be cannibals, as well as the tribe of the Karoans, in the mountains of the north coast, between Amberbaki and the two small islands Amsterdam and Middelburg, * and the tribe of the Tarungarays on the east coast of Geelvinks Bay. Here on Jobie, as everywhere on New Guinea, the coast Papooas are in perpetual war with the mountain tribes. Perhaps because some individuals of the latter believed us to be more friendly to the inhabitants of Ansus than to themselves, or that they required no special reason for fighting, once without any warning or provocation we were attacked with spears and arrows; but I afterwards took such precautions and frightened them to such a degree, that during our whole stay here we experienced nothing further disagreeable. The Papooas of Jobie have everywhere the bad reputation of being wild and quarrelsome.

After having left Jobie, from which I set ou with a heavy. heart-I should have liked to remain longer-I went as

* When back at Dorey in July, the natives here were very much frightened, because the Karoans near Amberbaki had just robbed and destroye a trading vessel, and killed or enslaved the crew. 
far to the east as the river Amberno, in fact to the northeast corner of Geelvinks Bay, and then shipped to the south-west, along the coast, landing and hunting from time to time, and trying to find a favourable place for a longer stay, and a spot from which it would be possible for me to penetrate into the interior, or to cross the island.

I did not succeed till I reached the south point of the bay. Here 1 found a little tribe of Papooas, who treated me from the beginning to the end in the most friendly way. On this account, and because I enjoyed a very favourable hunting-ground (immediately after going ashore I got four different species of birds of Paradise), I remained here for some weeks. Shortly after having anchored, even the young girls came on board the ship together with the men, and remained there for hours, whereas, in other parts, the women generally are very shy and keep aloof.

Seeing that I could trust the natives here, I tried to carry out my project of crossing the country to the coast opposite the Aru Islands. But even if I had not come so far, for reasons which it would be out of place to give in this brief account of my journey, I got some interesting additions to our geographical knowledge, ${ }^{*}$ and was very much satisfied with my zoological collections.

But I would not give up my plan of crossing New Guinea, and therefore proceeded near the coast to the north-west, looking out everywhere for a convenient starting-point, and gathering every possible information from the natives. But the island was still too broad here; the Papooas knew nothing of the opposite coast, as they do not migrate so far.

The natives of these western coasts of Geelvinks Bay are all afraid of the Wandamman tribes, whereas those of the eastern coasts are afraid of the Waropin tribes; but generally the vast country here is very poorly populated, there being few settlements, and these few small ones.

The point where I crossed the island at last into MacCluer Gulf of the south-west coast was situated $134^{\circ} 18^{\prime} \mathrm{E}$., $20^{\circ} 38^{\prime} \mathrm{S}$. I went first to the north-west, and then, after having passed several mountain chains $(2, \infty 00$ $\mathrm{ft}$.$) , to the west, down a fine river called the Jakati, through$ the country of Onim. It was, perhaps, lucky for me that I could only get a very small native prau here, else I would have proceeded farther west by sea, (the swamps render it impossible to go by land), and possibly encountered dangers from the natives of the MacCluer Gulf, who have not the best reputation, and who certainly would have felt inclined to revenge their countrymen, killed by the Italian Cerruti and his company, some years ago.

I need not say that this journey from one side of New Guinea to the other has never been made before; and I should hardly myselfattribute any importance to the fact, were it not for the reason that till then we did not know exactly whether there existed a communication by water from Geelvinks Bay to MacCluer Gulf or not. We may be convinced now that it does not exist.

From Geelvinks. Bay I tried to ascend the Arfak Mountains from the south, but did not succeed, because I ran short of provisions. The country seemed uninhabited, or, without Papooan guides as I was, and with

* The geographical part of my expedition will be published very soon, accompanied by a chart, in Petermann's Mittheilungen. only some of my Malay companions, I missed the few native houses and small plantations in the neighbourhood, scattered here and there, so that it was not advisable to go too far into the country. Besides, I did not find in the forests on the southern slopes of the Arfak Mountains those gems of the bird-world which I hoped to find, and therefore left these regions and penetrated from the north with better success. It will be interesting for English ornithologists to learn that I succeeded in finding here $(3,000-6,000 \mathrm{ft}$. $)$ all the known Birds of Paradise of New Guinea (except the species from the islands), besides a new one, and a quantity of other most curious and rare specimens, the ornis of the mountains being quite different from that of the seashore. But here also, as on the whole of New Guinea, I was astonished to see that the fauna generally is not rich. The forms found in the country certainly are curious and characteristic, but, in comparison with the enormous mass of forest, they are everywhere very scarce, and it is an exception to find a hunting-ground where much is to be got in a short space of time. It is the same in New Guinea as I found it in Celebes, where more of the life of nature is to be seen and heard near the seashore and the settlements than in silent virgin forests.

I hope that now, since the interior of New Guinea is opened, at least as the way is known how to penetrate into one part of it, other naturalists will soon succeed in reaping more important results than it was my lot to obtain.

\section{AdOLF BERNHARd MEYER}

\section{MICROSCOPIC PETROGRAPHY}

Iikikroskopische Physiographie der petrographisch wichtigen Mineralien ein Hülfsbuch, bei mikroskopischen Gesteinstudien. H. Rosenbusch. With IO2 woodcuts and ten coloured plates. (Stuttgart.)

SINCE we last called attention to this subject in the columns of NATURE it has been making steady progress, chiefly among our German, that is, of course, German-speaking, brethren of the hammer and lens. The various serials which treat of Geology and Mineralogy bear witness to this progress, and to the wonderful activity of some of the workers, such as our good friends Zirkel and Tschermak, to whom it is so largely due. And now here comes a goodly octavo of some four hundred pages as a further contribution to our knowledge, and a fresh proof of the strong hold which the microscopic study of minerals and rocks has taken of the German geognostical mind. This activity need not be matter for wonder when one considers the chaos into which matters petrographical had got even in Germany. Those who studied rocks in that country had become a sort of bound thralls to chemists and chemical analysis. They dared not trust their eyes to discriminate the differences of species and varieties. The specimens must be handed over to the laboratory, and on the judgment thence obtained depended the names by which the compounds should be known thenceforward throughout Christendom. By this means, as the composition of a rock often differs considerably in different, and even in closely-adjoining, parts-variations resulting partly from original discrepancies, and partly from internal changes due to the subsequent infiltration 